\title{
Ecosystem-based Adaptation to Drought among Agro-pastoral Farmers: Opportunities and Constraints in Nakasongola District, Central Uganda
}

\author{
David Mfitumukiza \\ Makerere University Centre for Climate Change Research \& Innovations \\ P.O. Box 7062 Kampala, Uganda \\ Bernard Barasa \\ Makerere University Centre for Climate Change Research \& Innovations \\ P.O. Box 7062 Kampala, Uganda \\ Ntale Emmanuel \\ Department of Forestry, Biodiversity and Tourism, Makerere University \\ P.O. Box 7062 Kampala, Uganda
}

Received: February 10, 2017 Accepted: March 7, 2017

doi:10.5296/emsd.v6i2.11132 URL: https://doi.org/10.5296/emsd.v6i2.11132

\begin{abstract}
Understanding the context and importance of ecosystem-based adaptation (EbA) by agro-pastoralists is important for building climate resilient social and ecological systems amidst the changing climate. A cross-sectional survey was conducted to examine the EbA to drought by the smallholder farmers in Nakasongola District where a total of 100 respondents were randomly selected and subjected to interviews. To supplement on this information, a land use/cover spatial dataset of 2016 for Uganda was obtained and analysed to characterise and quantify the distribution of ecosystems utilised by the agro-pastoralists in the District. The spatial results revealed that the grassland (1524.6sq.km) and agricultural (agroecosystem) (779.1 sq. km) ecosystems were the largest ecosystems followed by the forest/woodland and freshwater ecosystems in terms of coverage. The farmers perceived severe droughts to occur between December to January for the last 30 years with an average of 4 years return period.
\end{abstract}


The agro and grassland ecosystems were the main contributors of drought adaptation opportunities compared to the freshwater and forest/woodland ecosystems. The direct and indirect opportunities involved goods and services such as water provision, mulching materials, food provision, fuelwood, regulation of air quality and water flow. However, the major constraints to EbA included rampant deforestation, limited knowledge on ecosystem conservation and overgrazing. Thus increasing water supplies for domestic and agricultural production is more likely increase the farmer's adaptation to drought.

Keywords: Drought, Ecosystem-based adaptation, Spatial distribution, Agro-pastoralists

\section{Introduction}

Drought and its characteristic extended period of moisture deficiency, greatly affects the smallholder agro-pastoral farmers, especially in the developing countries whose livelihood principally depends on the natural resources base coupled with minimum application of external farm inputs (Keil et al., 2008; Stringer et al., 2009; Fisher et al., 2015). Locally, the occurrence and severity of drought episodes, and the associated adverse effects on farmers' food security status, have been perceived to be triggered by uncontrolled or unsustainable practises such as widespread deforestation, wetland degradation and poor farming methods (Malhi et al., 2008; Islam \& Sato, 2012; Silvestrini et al., 2011). The increasing vulnerability of smallholder agro-pastoral farmers to drought is attributed to high dependence on rain-fed agriculture and limited application of adaptation options (Gentle \& Maraseni, 2012; Rickards \& Howden, 2012; Moore \& Lobell, 2014). The drought affects farmers through reduced pasture quality/quantity and increased pests/parasites and disease incidences (Meze-Hausken, 2004; Zarafshani et al., 2012), and reduced income levels (Rojas et al., 2012; Keshavarz \& Karami, 2014). In response to some of these effects, depending on the capacity and awareness, some farmers, have keenly applied various drought adaptation in-situ and ex-situ options such as planting drought-tolerant pasture and crop varieties, mulching, application of organic and inorganic fertilizers and construction of valley dams among others (Mwangi, 1996; Tin et al., 2001; Vaneeckhaute et al., 2013). These modest adaptation options have been deemed as good by the smallholder farmers. However, these are limited in terms of scope due to their in consideration of sustainable ecosystem resource management practices, conservation and restoration (Slegers \& Stroosnijder, 2008; Huq et al., 2012).

Several researchers (Price et al, 2009; Habiba et al., 2012; Pramova et al., 2012) have worked to seek relevant and applicable adaptation options to drought. Ecosystem-based adaptation has proved to be one the most effective and sustainable adaptation option (Munang et al., 2013; Wamsler et al., 2014). In agro-pastoral communities, agricultural and non-agricultural practices that make use of biodiversity and ecosystem services to facilitate adaptation to drought constitutes EbA in its broadest sense (Huq et al., 2012; Häyhä, et al., 2015). According to Munang et al., 2014, the ecosystem-based adaptation uses biodiversity and ecosystem services as part of an overall adaptation strategy to help farmers adapt to the negative effects of climate change and variability including drought prevalent at local, national, regional and global levels. The EbA is a cost-effective and sustainable approach to improving farmer's vulnerability to drought (Wertz-Kanounnikoff et al., 2011; Pasquini \& 
Cowling, 2014). Ecosystem benefits can be classified as provisioning, regulating and supporting services, with cultural services perceived as playing a lesser role in terms of adaptation to drought (Raudsepp-Hearne et al., 2010; Abson \& Termansen, 2010; Seidl et al., 2016). For example, the adoption of $\mathrm{EbA}$ in an agricultural system through the implementation of sustainable land and tree planting practices offers more opportunities for the farmers such as to diversify/increase their sources of income, provision of timber and food which are important in enhancing their food security status (McNeely \& Schroth, 2006; Macadam \& Stockan, 2015; Fagerholm et al., 2016).

Few studies (Naidoo \& Adamowicz, 2005; Akwetaireho \& Getzner, 2010; Mercer et al., 2012; Hills et al., 2013; Ahammad et al., 2013; Osano et al., 2013; Namaalwa et al., 2013), have documented the opportunities and constraints of EbA in helping agro-pastoral farmers adapt to drought especially in the developing world. This study employs geographical information systems (GIS) to provide information on the spatial distribution of ecosystems over heterogeneous landscapes which are rarely mapped, classified and aggregated (Debinski et al., 1999; Perry \& Millington, 2008; Staudhammer et al., 2015). This is important for the holistic understanding of the general characteristics and patchiness of ecosystems prevalent in a given region. The application of GIS and remote sensing is useful in providing much needed spatial information to aid decision making in ecosystem adaptation to drought (Manor \& Shnerb, 2008; Usali \& Ismail, 2010; Fabri et al., 2014). Spatial information also helps to derive meaningful environmental parameters such as biophysical characteristics and their distribution (Mackey \& Lindenmayer, 2001; Turner et al., 2003; Barbar et al., 2015). Hence, examining the spatial distribution of ecosystems is critical in documenting the distribution and extent of ecosystems and their drought adaptation opportunities over space and time.

Therefore, this study sought to achieve an understanding of the occurrences of drought, impacts on the farmers, the spatial distribution of ecosystems, opportunities and constraints in a semi-arid region. The specific objectives of this study were to; examine the farmer's perceptions on drought and characterise the spatial distribution of ecosystems, opportunities and constraints faced by the farmers in Nakasongola District in Uganda. The results of this study heighten the understanding and importance of undertaking an ecosystem-based adaptation to drought by agro-pastoral farmers in semi-arid areas because of its focus on promoting sustainable natural resources management, conservation and restoration which are and should be part of an overall adaptation strategy, especially for natural resources dependent farmers. This study also seeks to advocate for the recognition of EbA in the formulation and amendment of climate change related policies and programmes because the economies and livelihoods of developing countries entirely depend on ecosystem services and biodiversity. In addition, the results will inform/guide the policy makers and researchers to make decisions from an informed perspective aimed at ecosystem accessibility, utilisation and conservation.

\section{Materials and Methods}

\subsection{Study Area}

This study was conducted in Nakasongola District $114 \mathrm{~km}$ north of Kampala. Within the 


\section{Macrothink}

district, two sub counties: Lwampanga and Nabisweera were selected out of 10 sub-counties (Figure 1). Lwampanga sub-county covers an area of $277 \mathrm{sq}$. km of land; while Nabisweera covers $742.8 \mathrm{sq} . \mathrm{km}$. In terms of topography, both sub-counties lie on the central plateau of Uganda that ranges between 616 and 1,157 metres above sea level. The sub-counties are among those reported to experience severe drought events and endowed with a diversity of ecosystems. The most dominant soil types that underlie the sub-counties include Gleyic arenosols, Histosols and Petric Plinthosols (Nabalegwa et al., 2007). The annual rainfall received varies from $875-1120 \mathrm{~mm} /$ annum with two distinct rainy seasons. The average surface temperature ranges between $22.6^{\circ} \mathrm{C}$ and $24.6^{\circ} \mathrm{C} /$ annum in the dry and wet seasons correspondingly.

The main vegetation types are characterised with woodland savannah, thicket and softwood plantations. The wetland cover types are composed of papyrus, seasonal bushes, thickets and grasslands. The two sub-counties have a share of one of Uganda's major lakes i.e. Kyoga, and also seasonal rivers such as Kasakwa, Muganwa and Wabay rivers, which impact the drainage system of the lake. Lwampanga sub-county had a total population of 29,741 people while Nabisweera had 16,461 people (Uganda Bureau of Statistics, 2016). Agriculture is the main source of livelihood in the area. Eighty-nine percent of the population is composed of subsistence farmers. Another significant source of livelihood is fishing, which is undertaken along the Lake Kyoga belt. Therefore, the agricultural sector contributes to the nutritional welfare of the people, provides employment, and generates substantial incomes virtually all year.

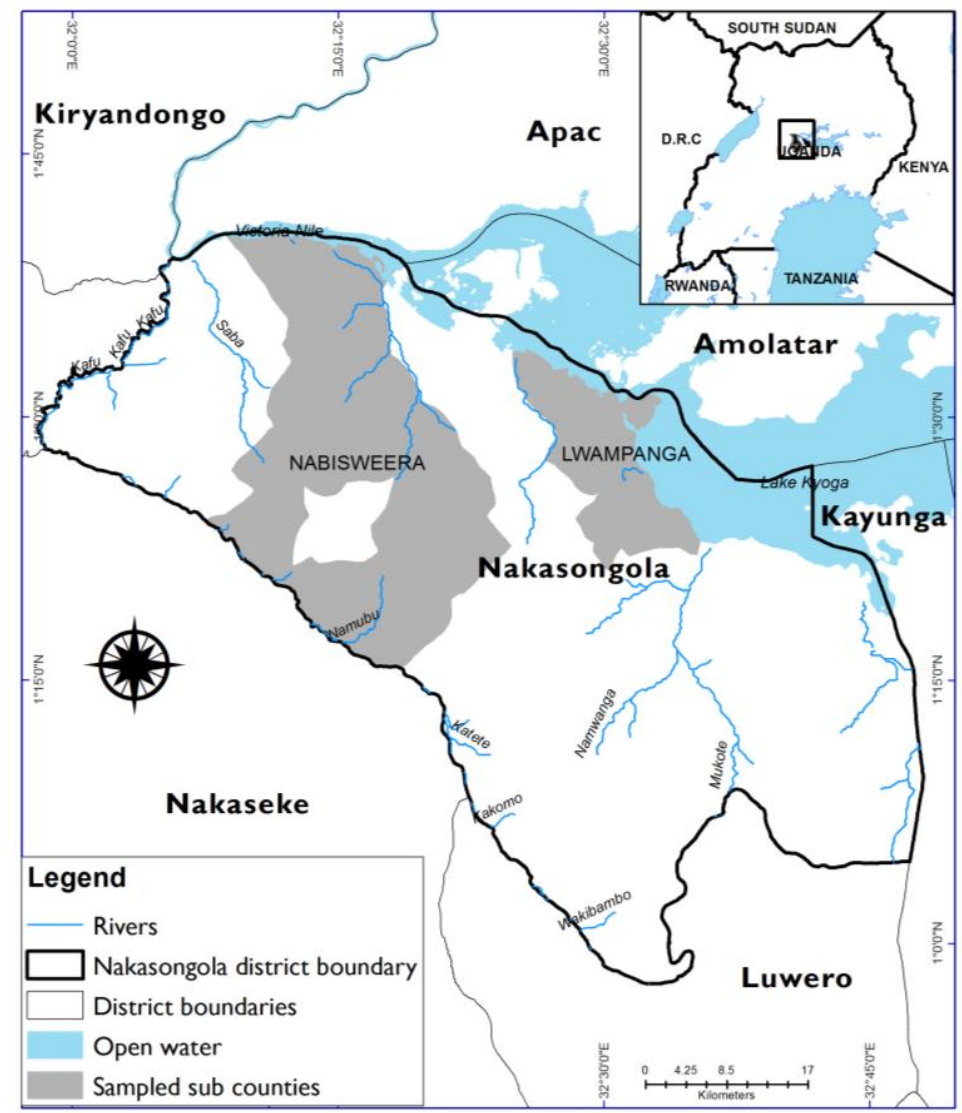

Figure 1. Location of study area 


\subsection{Socio-economic Data Collection}

This study took an EbA approach to establish the spatial distribution of ecosystems, opportunities and constraints faced by the agro-pastoral farmers in adapting to drought. This is a holistic approach that recognised the interconnectivity between ecological, social-cultural, economic and institutional assessment (Munang et al., 2014). In the selection of study respondents, the agro-pastoral farmers were sampled at village levels using local council member's lists with the guidance of local leaders in both Lwampanga and Nabisweera sub-counties. In the selected sub-counties, the study assumed that each farmer had an equal chance of accessing and utilising at least more than one ecosystem. The randomly sampled agro-pastoral farmers totalled to 100, with 50 farmers sampled from each sub-county. Only respondents who had lived in the sub counties for the last 30 years were considered for interviewing as one of the quality measures.

A household questionnaire survey of agro-pastoral farmers was conducted to collect data on EbA to drought in the selected sub-counties which included but not limited to drought occurrence and its impact, EbA opportunities and constraints. The farmers were randomly selected to avoid biases in the sampling framework. This survey was conducted during the dry season in the month of January 2016, when the ecosystem-based adaptations to drought were assumed to be at the peak. The selected respondents were personally interviewed with the aim to generate individual responses on EbA to drought during the course of the day. The farmers were interviewed and their responses recorded on a questionnaire for later retrieval of information. The interview sessions were conducted from the farmer's premises.

Similarly, the study also conducted interviews with the key informants involved in natural resources management with the aim to generate broader insights on the EbA opportunities and constraints faced by the farmers. The interviewed informants included the district natural and agricultural officers, community-based organisation leaders and agro-dealers. In addition, four focus group discussions were conducted, two from each sub-county of randomly selected farmers for interviewing. The groups comprised of 10-12 agro-pastoral farmers including both men and women. These were conducted purposely to collect farming community level perspectives and opinions on drought occurrence, EbA opportunities and constraints. The discussions were held at the sub-county headquarters. The obtained responses from the household questionnaire survey were cross-checked for inconsistencies and corrected before entry into the statistical software. The questionnaires were pre-coded and responses entered in a Statistical Package for Social Scientists (SPSS) software version 16 for statistical analysis to obtain information on EbA to drought in Nakasongola District. A statistical test (Chi-square) was used to test for differences among the sampled respondents' land sizes, crop growing, tree planting and livestock rearing $\left(\mathrm{X}^{2}\right.$ test) in the studied sub-counties. The collected was analysed for frequencies and the results presented in form of tables and graphs.

\subsection{Spatial Distribution of Ecosystems}

The assessment of spatial distribution of ecosystems was based at District level and not selected sub-counties because of the interdependencies of ecosystems and their functions at a 


\section{Ml Macrothink}

Environmental Management and Sustainable Development

ISSN 2164-7682

2017, Vol. 6, No. 2

landscape scale. The spatial assessment was based on the present land use/cover dataset (2016) acquired from the Uganda National Forestry Authority; which is the mandated government institution meant to frequently monitor changes in land use/cover in Uganda. The obtained vector based dataset was checked and corrected for inconsistencies such as the appropriate location and extent of mapped land use/cover types, topologies; and collated with the other existing national datasets (wetlands, protected areas etc) using ArcGIS software platform version 10.1. The study area was masked out of the obtained land use/cover dataset for faster display and rendering. The prevailing land use/cover classes for Uganda are well described and explained in detail by Drichi (2003). In characterising the spatial distribution of ecosystems, we assumed that the prevailing land use/cover types represented different ecosystems. The distinct land use/cover classes were spatially merged to form four broader categories of ecosystems based on their descriptions (Table 1).

In addition, the spatial distribution of ecosystems was also checked by examining the secondary data sources such as the district state of environment reports and selective interviewing of key informants in the studied sub-counties. The selected key informants for this purpose included clan elders and local council leaders (including men and women); given their roles and responsibilities such as land allocation, transfer and land utilisation among others. These were conducted with the aim to confirm the location, pattern and utilisation of ecosystems by the agro-pastoral farmers. The final information on the spatial distribution of ecosystems and their acreage is presented in form of a map and table considered as appropriate outputs from a GIS system to aid spatial decision making.

Table 1. Land use/cover classes and ecosystems categories

\begin{tabular}{|c|c|c|}
\hline No & Land use/cover classes & Ecosystems categories \\
\hline & Broad-leaved plantations & \multirow{5}{*}{ Forest/woodland ecosystem } \\
\hline \multirow[t]{4}{*}{1} & Needle-leaved plantation & \\
\hline & Tropical High Forest well stocked & \\
\hline & Tropical high forest low stock & \\
\hline & Woodland & \\
\hline \multirow[t]{2}{*}{2} & Bushlands & \multirow[t]{2}{*}{ Grassland ecosystem } \\
\hline & Grassland & \\
\hline \multirow[t]{2}{*}{3} & Wetland & \multirow[t]{2}{*}{ Freshwater ecosystem } \\
\hline & Open Water & \\
\hline \multirow[t]{2}{*}{4} & Small scale farmland & \multirow[b]{2}{*}{ Agro-ecosystem } \\
\hline & Commercial farmland & \\
\hline
\end{tabular}




\section{Macrothink

\section{Results}

\subsection{Farmers'Perceptions on Drought Occurrences and Impacts}

\subsubsection{Seasonal Drought Occurrences}

The majority of the respondents perceived that the occurrences of droughts were more severe between December and January (55\%) for the last 30 years. While the May to August and November to March periods were also recognised as prone to mild droughts (Table 2). The farmers perceived the occurrences of severe droughts to occur on average of every four years.

Table 2. Perceptions on drought occurrences

\begin{tabular}{|l|l|}
\hline Seasonal Periods & Percent \\
\hline December to January & 55 \\
\hline August to November & 14 \\
\hline May to August & 16 \\
\hline November to March & 15 \\
\hline
\end{tabular}

\subsubsection{Perceived Impacts of Drought on the Agro-Pastoral Farmers}

The farmers categorised the impacts of drought into three major classes as reported by the majority $(95 \%)$ of the respondents in Table 3. In livestock rearing, the perceived impacts of drought included reduced pasture quality and quantity and increased parasite and disease incidences. These effects were recognised throughout the sub-counties. While in crop production, the perceived impacts of drought were much more felt through increased occurrences of crop pests and diseases and loss of crops before maturing. These were followed by reduced soil moisture content and increased termite activity that underscored the success of crop production. These impacts were reported to be more rampant in the months of December and January. The water resources were also affected through reduced water quality and quantity and degradation of wetlands. These were followed by loss of fish and siltation of surface dams. The impacts were significantly experienced in the months of January and February of each year. The reductions in the water tables were largely experienced on Lake Kyoga and River Kafu water bodies. The study revealed that the agroecosystem was the most affected ecosystem by drought which is the main source of livelihood that enhanced their food security status. 


\section{Macrothink \\ Environmental Management and Sustainable Development \\ ISSN 2164-7682 \\ 2017, Vol. 6, No. 2}

Table 3. Perceived impacts of drought on the agro-pastoral farmers

\begin{tabular}{|c|c|c|}
\hline Categories & Impacts & Percent \\
\hline & Reduced pasture quality and quantity & 32 \\
\hline \multirow{6}{*}{ Livestock production } & Loss of livestock & 6 \\
\hline & Increased parasite and disease incidences? & 20 \\
\hline & \begin{tabular}{|l|l} 
High costs of feeds \\
\end{tabular} & 8 \\
\hline & Low yields & 13 \\
\hline & Increased crop pests and diseases & 12 \\
\hline & Reduced soil moisture content & 9 \\
\hline \multirow{5}{*}{ Crop production } & Human - wildlife conflicts & 9 \\
\hline & Insect infestations (termite activities) & 17 \\
\hline & Loss/ damage of crops & 38 \\
\hline & Reduced water quality and quantity & 21 \\
\hline & Siltation of dams & 15 \\
\hline \multirow{3}{*}{ Water } & Degradation of wetlands & 62 \\
\hline & Loss of fish due to low water & 27 \\
\hline & Damage to fish habitats & 11 \\
\hline
\end{tabular}

\subsection{Spatial Distribution of Ecosystems}

Table 4 and Figure 2 below revealed that the grassland ecosystem was the most widely distributed ecosystem covering 43.5 percent of the landscape in the year 2016. Most of the grassland ecosystem patches were largely found along both the permanent and seasonal river systems across the district. This was followed by the agro and forest/woodland ecosystems that also characterised the entire landscape. The peak of agricultural related activities and rejuvenation of forests/woodland ecosystem were reported to be high during the mid-rainy seasons. This was followed by the coverage of both permanent and seasonal freshwater ecosystems. In the north, lies Lake Kyoga and River Kafu in the south-west. Wetlands were located along rivers/streams, Lake Kyoga shoreline and in the central forest reserves. The study results also revealed that the forest/woodland and agroecosystems occupied almost an equal area of land across the district. In addition, based on the observations made by $87 \%$ of the key informants in all the reported ecosystems, they attributed the variations in the patchiness of agricultural, grassland, freshwater and forest/woodland ecosystems to the intensity and increased the frequency of drought events in determining their locational and utilisation. 


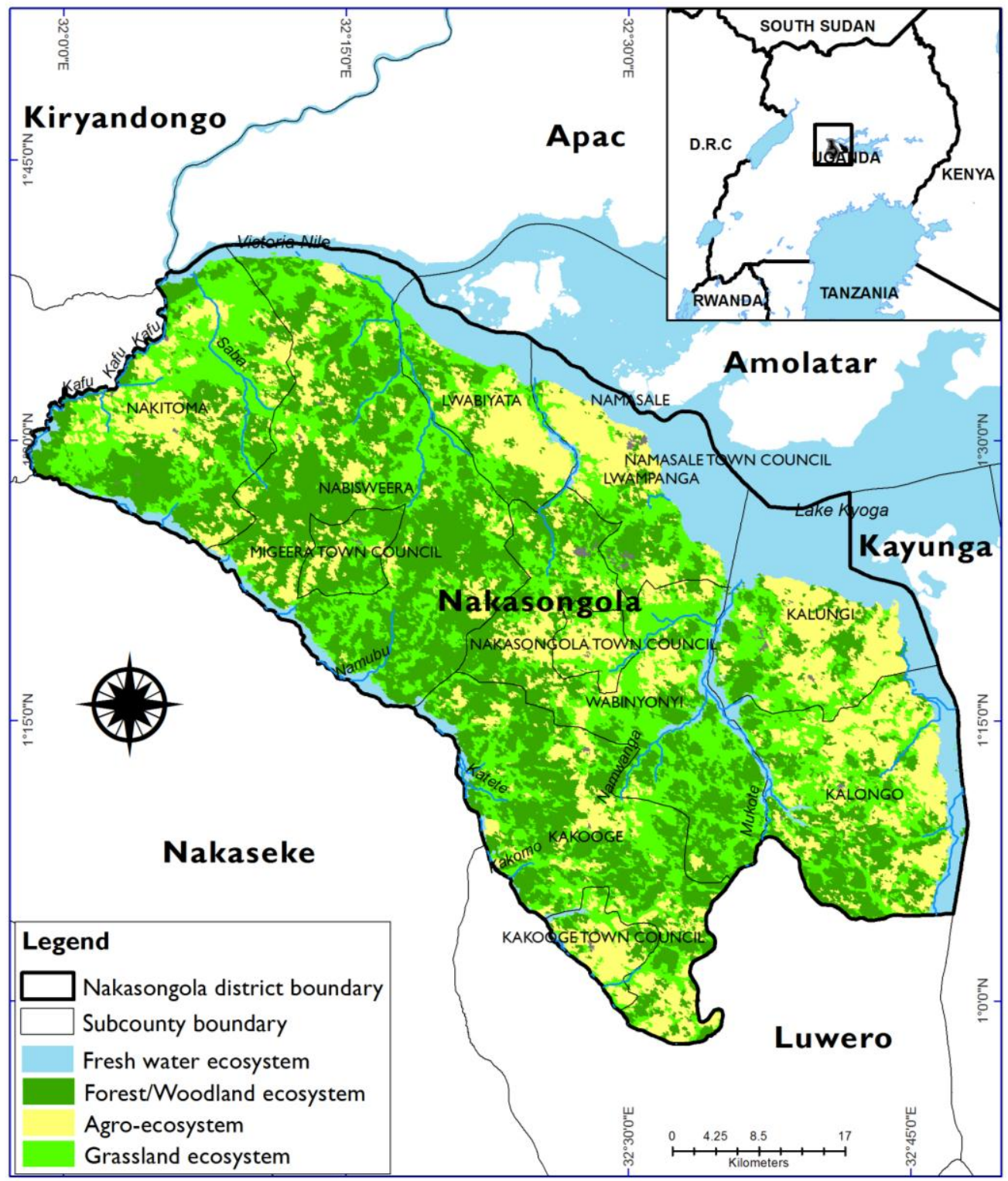

Figure 2.Spatial distribution of ecosystems in Nakasongola District

Table 4. District spatial distribution of ecosystems

\begin{tabular}{|l|l|}
\hline \multicolumn{2}{|l|}{ Spatial coverage of ecosystems } \\
\hline Ecosystems & Area (sq.km) \\
\hline Forest/woodland ecosystem & 717.5 \\
\hline Grassland ecosystem & 1524.6 \\
\hline Freshwater ecosystem & 478.0 \\
\hline Agro-ecosystem & 779.1 \\
\hline
\end{tabular}




\subsection{Opportunities and Constraints of Ecosystem-Based Adaptation to Drought}

\subsubsection{Opportunities}

Table 5 below shows that the ecosystem-based adaptation opportunities varied from one ecosystem to another. In this section, the opportunities are quantified and grouped in terms of benefits from each ecosystem as perceived by the farmers. From the sampled farmers, the freshwater ecosystem goods and services benefited the farmers through the provision of water (for domestic use and irrigation), art and craft raw materials (papyrus reeds) and fish harvests (Nile perch, Tilapia) (Plate 1). The peak of these harvests was highly reported in the months of April and June which marked the onset of the dry season. Whereas, the goods derived from the forest ecosystem included fuelwood, wild fruits, medicines and building materials (poles and thatch grass) which were reported to be highly harvested in the months of December, January and February of each year. The notable forest ecosystem which accrued the most benefits to the agro-pastoral farmers included Wabisi-Wajala central forest reserve in Lwampanga sub-county.

Similarly, the agro-pastoralists also depended on the grassland ecosystem for the acquisition of mulching materials and pasture for feeding livestock during the extreme months of drought. The respondents revealed that the agroecosystem mostly helped them to adapt through the provision of food, hence enhancing their food security status. The most commonly harvested fruits included mangoes, guavas and wild tomatoes among others. The Forest/woodland ecosystems were reported to offer the highest diversity of ecosystem services to the farmers such as regulation of air quality and water flow and storage regulation. The other goods and services included soil fertility improvement, reduced soil erosion, flood control, aesthetic value (tourism) and restoration of wetlands.

The majority of the agro-pastoral farmers (84\%) revealed that they had free access to all the ecosystem opportunities when their need arose for utilisation. The respondents also explained that biodiversity and ecosystem services were accessed by farmers even beyond the district. The ecosystem goods and services were largely reported by the majority of the farmers $(70 \%)$ to have been harvested because of their direct benefits in livelihood enhancement. Most of the harvested ecosystem products were sold in the markets (57\%), while $43 \%$ of the products were consumed in homes.

Table 5. Ecosystem goods and services

\begin{tabular}{|l|l|}
\hline Ecosystem goods & Percentage \\
\hline $\begin{array}{l}\text { Freshwater ecosystem } \\
\text { Water provision }\end{array}$ & 82 \\
\hline Fish catch & 8 \\
\hline Provision of art and craft raw materials & 10 \\
\hline Forest/ woodland ecosystem & \\
\hline Fuelwood & 70 \\
\hline Wild fruits & 23 \\
\hline Building materials & 5 \\
\hline
\end{tabular}




\begin{tabular}{|l|l|}
\hline Medicines & 2 \\
\hline Grassland ecosystem & \\
\hline Mulching materials & 96 \\
\hline Fodder for animal & 4 \\
\hline Agro-ecosystem & \\
\hline Provision of food & 70 \\
\hline Provision of fruits & 30 \\
\hline Ecosystem services & Percentage \\
\hline Regulation of air quality & 49 \\
\hline Water flow and storage regulation & 16 \\
\hline Soil fertility improvement & 15 \\
\hline Reduction of soil erosion & 8 \\
\hline Flood control & 5 \\
\hline Maintain and increased resilience of crops & 3 \\
\hline Aesthetic Values (tourism) & 2 \\
\hline Maintenance of habitats & 2 \\
\hline
\end{tabular}
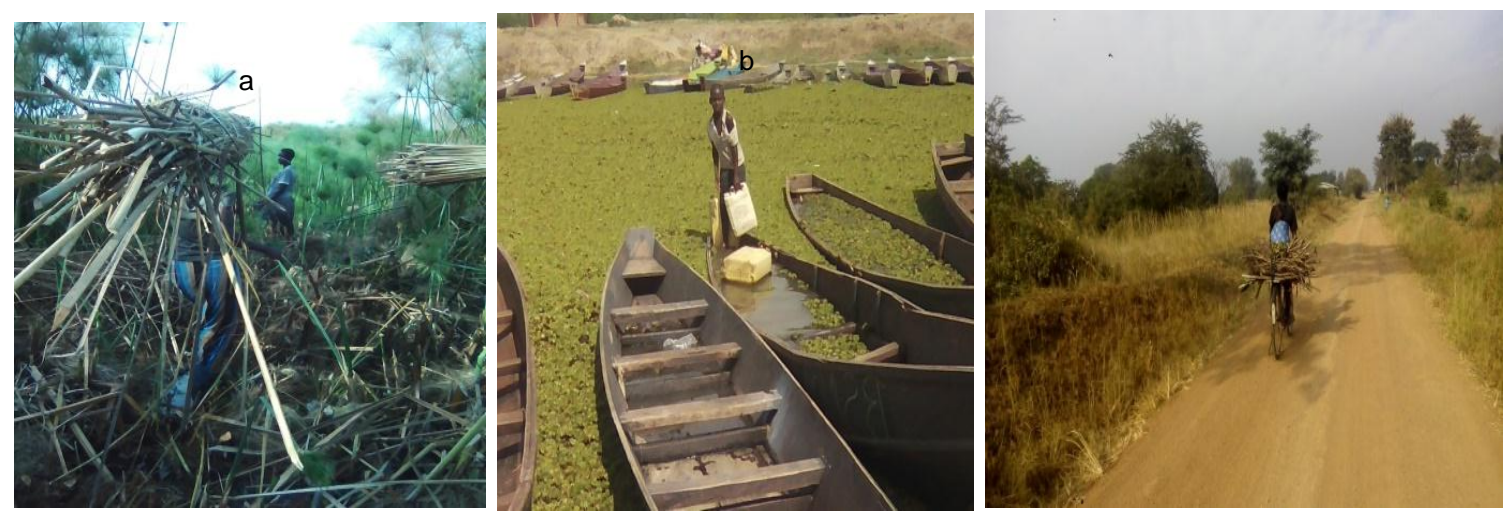

Plate 1. (a) Harvesting of papyrus reeds from wetlands to make mats for diversification of income during drought periods, (b) Lakes and wetlands act as sources of water for domestic use during periods of prolonged drought on L. Kyoga, (c) female farmer carrying fire wood collected from the forest ecosystem in Lwampanga sub-county

\subsection{Practices Undertaken to Conserve Ecosystems}

In forest/woodland ecosystem, a large number of farmers were engaged in wildfire prevention and enrichment planting in sustaining EbA to drought, while a sizeable number were involved in establishing exotic and indigenous tree plantations (Table 5). In the grassland ecosystem, most of the farmers were also engaged in bushfire prevention and fighting measures followed by undertaking controlled grazing and fodder planting. Whereas, in the freshwater ecosystem, conservation efforts were geared towards protecting the watersheds and shoreline through tree planting; followed by buffer zone enforcement and water weed collection. In the agroecosystem, the majority of the farmers practised intercropping (trees/banana/coffee), 


\section{Macrothink}

Environmental Management and Sustainable Development

ISSN 2164-7682

2017, Vol. 6, No. 2

planted trees followed by control of soil erosion and bushfires (Table 5). Generally, the uncontrolled bushfires were the most reported incidences that degraded the ecosystems; and thus deprived the farmers of attaining ecosystem good and services.

Table 6. Ecosystem-based adaptation practices to drought

\begin{tabular}{|c|c|c|c|}
\hline No & Ecosystems & EbA practices & Percent \\
\hline \multirow{6}{*}{1} & \multirow{6}{*}{ Forest/woodland ecosystem } & Exotic plantations & 12 \\
\hline & & Wildfire prevention & 46 \\
\hline & & Natural regeneration & 5 \\
\hline & & Enrichment planting & 16 \\
\hline & & Restricted grazing & 9 \\
\hline & & Indigenous plantations & 12 \\
\hline \multirow{3}{*}{2} & \multirow{3}{*}{ Grassland ecosystem } & Controlled grazing & 32 \\
\hline & & Bushfire prevention & 56 \\
\hline & & Fodder plantation & 12 \\
\hline \multirow{4}{*}{3} & \multirow{4}{*}{ Freshwater ecosystem } & Watershed protection & 53 \\
\hline & & Shoreline protection & 30 \\
\hline & & Water weed harvesting & 5 \\
\hline & & Buffer zone enforcement & 12 \\
\hline \multirow{4}{*}{4} & \multirow{4}{*}{ Agro-ecosystem } & Intercropping & 37 \\
\hline & & Erosion control & 24 \\
\hline & & Fire management & 9 \\
\hline & & Tree planting & 30 \\
\hline
\end{tabular}

\subsection{Perceived Constraints Faced By the Farmers in Ecosystem-Based Adaptation to Drought}

The agro-pastoral farmers indicated that deforestation related activities within the forest/woodland ecosystem were the main constraints that deprived them from attaining ecosystem goods and services, especially during the dry season (Figure 4). The activities undermined the survival of vegetation at the cost of diversifying sources of income and livelihood resources in Nabiswera and Lwampanga sub-counties. The second constraint was limited knowledge in estimating the importance of ecosystem and natural resources in adapting to drought which culminated into the farmer's flippant actions. Overgrazing due to overstocking and fencing of public grazing lands was also reported as a major constraint to ecosystem-based adaptation to drought. Other constraints included weak enforcement of environmental protection laws and policies. 


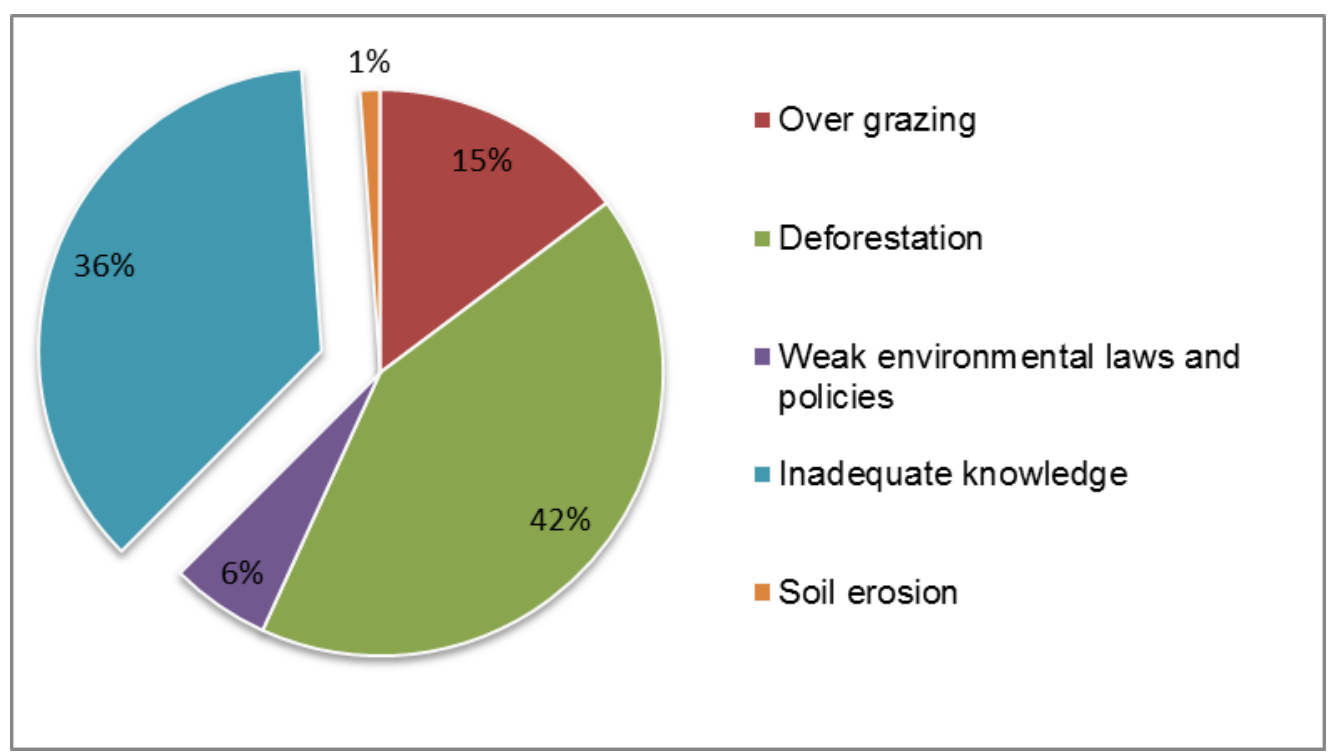

Figure 4. Perceived constraints to ecosystem-based adaptation to drought

\section{Discussion}

This study aimed at examining ecosystem-based adaptation to drought by the smallholder farmers in Nakasongola district. The findings revealed that the farmers experienced drought in the months of December to January of each seasonal year since the late 1980s to date. The agro-pastoralists mainly attributed the high occurrences and severity of drought to local anthropogenic factors such as deforestation, wetland degradation and poor farming methods. This finding was expected given the communal type of grazing and the amount of rainfall received. These activities were undertaken by the farmers purposely to diversify/increase their sources of income including through increased area under agriculture. Similar findings were also reported by Zziwa et al. (2012) in Nakasongola district about the occurrences of droughts in the periods 1983-1989 and 2001-2004. Nimusiima et al. (2013) also found out that the occurrences of droughts in Nakasongola were largely perceived to be caused by indiscriminate tree cutting other than the known scientific reasons. Elsewhere in Uganda, Osbahr et al. (2011) also showed that the farmers had observed detailed accounts of drought characteristics during specific years, with more severe droughts experienced in the late 1990s and late 2000s that presented lesser favourable condition for livestock and crop production.

Before understanding the ecosystem-based goods and services, characterising their spatial distribution plays a vital role in the adaptation to drought. In this case, the grassland ecosystem was the most widely spatially distributed ecosystem in the Nakasongola District. This distribution was as a result of its geographical location in the semi-arid area characterised with low rainfall and deforestation activities. Mugerwa \& Emmanuel (2014) also argued that the grasslands of Uganda occupy what is commonly referred to as the "cattle corridor", an area stretching from the north part (Karamoja region), through the central (e.g. Nakasongola and Luwero Districts) to the southwestern parts of the country. The study area exhibits most of the characteristics of rangelands in Uganda; low and erratic rainfall regimes 
leading to frequent and severe droughts, and fragile soils with weak structures which render them easily eroded (Kisamba-Mugerwa, 2001). In terms of ecosystem goods and services, the freshwater ecosystem benefited the farmers through the provision of water, art and craft raw materials and fish harvests. Secondly, the forest/woodland ecosystem benefited the farmers through the provision of fuelwood, wild fruits, medicines and building materials (poles and thatch grass), while the grassland ecosystem benefited them through the acquisition of mulching materials and pasture for livestock during the extreme months of drought. Nevertheless, the ecosystem benefits deteriorated due to increased termite activity and overstocking of livestock that reduced the quality of pasture resulting into bare-lands (Mugerwa et al., 2011). Similar findings were also reported by Byenkya et al. (2014) that changes in demand for food, pasture and fuelwood led to changes in agroecosystem, grassland and forest/woodland ecosystems, affecting livestock management practices.

Land use and cover change related activities within the forest/woodland ecosystem were the main threats to farmers' continued benefit from the flow of goods and services. The rampant deforestation activities were attributed to the high demand for wood used for smoking fish and opening up of new cultivatable areas for agricultural production. The farmers' ability to enhance ecosystems ability to provide goods and services was hampered by limited knowledge about the conservation, restoration practices and regulations governing the ecosystems. Overgrazing was another constraint that threatened farmers' benefits from ecosystem for adaptation to drought. Farmers perceived the existence of high livestock stocking density that was attributed to the high demand for livestock products. According to livestock census by UBOS (2008), the local poultry were the most dominant birds reared by most of the households with a population of 282,645 followed by indigenous cattle with the population of 201,075. Nabiswera sub-county had a population of 52,860 cattle followed by Wabinyonyi sub-county with a population of 25,950 cattle.

Undoubtedly, the finding of this study clearly shows that EbA to drought offers opportunities and options for farmers' socio-economic resilience in Nakasongola district. Therefore, there is a huge need to promote awareness campaigns and knowledge creation on EbA, if the farmers are to harness the presented opportunities from biodiversity and ecosystem services. Future investigations may concentrate on the effectiveness of the ecosystem-based goods and services in adaptation to drought.

\section{Conclusion}

The negative impacts of drought were highly manifested in both crop and livestock production and threatened the agropastoralists food security. In terms of ecosystem-based adaptation to drought, the forest/woodland and grassland ecosystems were the major ecosystems that offered most of the needed goods and services for responding to the impacts of drought. Thus, ecosystem conservation efforts tailored towards felicitous ecosystem-based adaptation programmes to drought should be promoted.

In addition, understanding the occurrences of drought events is an important factor in supporting farmers to access and utilise biodiversity and ecosystem services in a way that minimises degradation, thus maintaining their ecological integrity. The findings further 
showed that the patches of agro-ecological ecosystems were more skewed towards the freshwater ecosystems mainly for purposes of extracting water for small-scale irrigation. The anthropogenic and institutional factors were the main underlying constraints faced by the farmers in ecosystem-based adaptation to drought.

EbA approach should be incorporated into agricultural extension programmes aimed at improving farmer's livelihood. This study, therefore, highlights which ecosystem-based adaptation practices are appropriate for smallholder farmers in agro-pastoral systems.

\section{Acknowledgement}

This study was financially supported by USAID and implemented through FHI 360 and Makerere University Centre for Climate Change Research and Innovations (MUCCRI). Great appreciation also goes to the Nakasongola District and local council officials who facilitated the data collection process in their respective sub-counties.

\section{References}

Abson, D. J., \& Termansen, M. (2010). Valuing ecosystem services in terms of ecological risks and returns. Conservation Biology, 25(2), 250-258.

https://doi.org/10.1111/j.1523-1739.2010.01623.x

Ahammad, R., Nandy, P., \& Husnain, P. (2013). Unlocking ecosystem based adaptation opportunities in coastal Bangladesh. Journal of Coastal Conservation, 17(4), 833-840.

https://doi.org/10.1007/s11852-013-0284-x

Akwetaireho, S., \& Getzner, M. (2010). Livelihood dependence on ecosystem services of local residents: a case study from Mabamba Bay wetlands (Lake Victoria, Uganda). International Journal of Biodiversity Science, Ecosystem Services \& Management, 6(1-2), 75-87. https://doi.org/10.1080/21513732.2010.521139

Barbar, F., Werenkraut, V., Morales, J. M., \& Lambertucci, S. A. (2015). Emerging ecosystems change the spatial distribution of top carnivores even in poorly populated areas. PLoS ONE, 10(3). https://doi.org/10.1371/journal.pone.0118851

Byenkya, G. S., Mugerwa, S., Barasa, S., \& Zziwa, E. (2014). Land use and cover change in pastoral systems of Uganda: Implications on livestock management under drought-induced pasture. African Crop Science Journal, 22, 1013-1025.

Debinski, D. M., Kindscher, K., \& Jakubauskas, M. E. (1999). A remote sensing and GIS-based model of habitats and biodiversity in the Greater Yellowstone Ecosystem. International Journal of Remote Sensing, 20(17), 3281-3291.

https://doi.org/10.1080/014311699211336

Drichi, P. (2003). National biomass study. National Biomass Study, Forest Department.

Fabri, M. C., Pedel, L., Beuck, L., Galgani, F., Hebbeln, D., \& Freiwald, A. (2014). Megafauna of vulnerable marine ecosystems in French mediterranean submarine canyons: Spatial distribution and anthropogenic impacts. Deep-Sea Research Part II: Topical Studies in 
Oceanography, 104, 184-207. https://doi.org/10.1016/j.dsr2.2013.06.016

Fagerholm, N., Torralba, M., Burgess, P. J., \& Plieninger, T. (2016). A systematic map of ecosystem services assessments around European agroforestry. Ecological Indicators. https://doi.org/10.1016/j.ecolind.2015.11.016

Fisher, M., Abate, T., Lunduka, R. W., Asnake, W., Alemayehu, Y., \& Madulu, R. B. (2015). Drought tolerant maize for farmer adaptation to drought in sub-Saharan Africa: Determinants of adoption in eastern and southern Africa. Climatic Change, 133(2), 283-299.

https://doi.org/10.1007/s10584-015-1459-2

Gentle, P., \& Maraseni, T. N. (2012). Climate change, poverty and livelihoods: Adaptation practices by rural mountain communities in Nepal. Environmental Science and Policy, 21, 24-34. https://doi.org/10.1016/j.envsci.2012.03.007

Habiba, U., Kogachi, A., Huy, N., Shaw, R., Srivastava, N., Prashar, S., \& Surjan, A. (2012). Ecosystem-Based Adaptation Understanding Adaptation Practices in Arid Land ecosystem. Community, Environment and Disaster Risk Management, 12. https://doi.org/10.1108/S2040-7262(2012)0000012013

Häyhä, T., Franzese, P. P., Paletto, A., \& Fath, B. D. (2015). Assessing, valuing, and mapping ecosystem services in Alpine forests. Ecosystem Services, 14, 12-23.

https://doi.org/10.1016/j.ecoser.2015.03.001

Hills, T., Carruthers, T. J. B., Chape, S., \& Donohoe, P. (2013). A social and ecological imperative for ecosystem-based adaptation to climate change in the Pacific Islands. Sustainability Science, 8(3), 455-467. https://doi.org/10.1007/s11625-013-0217-5

Huq, N., Renaud, F., \& Sebesvari, Z. (2012). Ecosystem Based Adaptation(EbA) to Climate Change- Integrating Actions to Sustainable Adaptation. United Nations University, Institute for Environment and Human Security (UNU-EHS), 14. https://doi.org/10.2312/pik.2013.001

Islam, K., \& Sato, N. (2012). Deforestation, land conversion and illegal logging in Bangladesh: the case of the Sal (Shorea robusta) forests. iForest-Biogeosciences and Forestry, 5(3), 171.

Keil, A., Zeller, M., Wida, A., Sanim, B., \& Birner, R. (2008). What determines farmers' resilience towards ENSO-related drought? An empirical assessment in Central Sulawesi, Indonesia. Climatic Change, 86(3-4), 291-307. https://doi.org/10.1007/s10584-007-9326-4

Keshavarz, M., \& Karami, E. (2014). Farmers' decision-making process under drought. Journal of Arid Environments, 108, 43-56. https://doi.org/10.1016/j.jaridenv.2014.03.006

Kisamba-Mugerwa, W. (2001). Rangelands management policy in Uganda. In International conference on Policy and Institutional Options for the management of rangelands in dry areas, 6-11.

Macadam, C. R., \& Stockan, J. A. (2015). More than just fish food: Ecosystem services provided by freshwater insects. Ecological Entomology, 40(S1), 113-123. 
https://doi.org/10.1111/een.12245

Mackey, B. G., \& Lindenmayer, D. B. (2001). Towards a hierarchical framework for modelling the spatial distribution of animals. Journal of Biogeography, 28(9), 1147-1166. https://doi.org/10.1046/j.1365-2699.2001.00626.x

Malhi, Y., Roberts, J. T., Betts, R. A., Killeen, T. J., Li, W., \& Nobre, C. A. (2008). Climate change, deforestation, and the fate of the Amazon. Science (New York, N.Y.), 319(5860), 169-72. https://doi.org/10.1126/science.1146961

Manor, A., \& Shnerb, N. M. (2008). Origin of pareto-like spatial distributions in ecosystems. Physical Review Letters, 101(26). https://doi.org/10.1103/PhysRevLett.101.268104

McNeely, J. A., \& Schroth, G. (2006). Agroforestry and biodiversity conservation Traditional practices, present dynamics, and lessons for the future. Biodiversity and Conservation. https://doi.org/10.1007/s10531-005-2087-3

Mercer, J., Kelman, I., Alfthan, B., \& Kurvits, T. (2012). Ecosystem-based adaptation to climate change in caribbean small island developing states: Integrating local and external knowledge. Sustainability, 4(8), 1908-1932. https://doi.org/10.3390/su4081908

Meze-Hausken, E. (2004). Contrasting climate variability and meteorological drought with perceived drought and climate change in northern Ethiopia. Climate Research, 27(1), 19-31. https://doi.org/10.3354/cr027019

Moore, F. C., \& Lobell, D. B. (2014). Adaptation potential of European agriculture in response to climate change. Nature Climate Change, 4(7), 610-614.

https://doi.org/10.1038/nclimate2228

Mugerwa, S., \& Emmanuel, Z. (2014). Drivers of grassland ecosystems' deterioration in Uganda. Applied Science Reports, 2(3), 103-111.

Mugerwa, S., Nyangito, M., Mpairwe, D., Bakuneeta, C., Nderitu, J., \& Zziwa, E. (2011). Termite assemblage structure on grazing lands in semi-arid Nakasongola. Agriculture and biology journal of North America, 2, 848-859.

Munang, R., Andrews, J., Alverson, K., \& Mebratu, D. (2014). Harnessing ecosystem-based adaptation to address the social dimensions of climate change. Environment: Science and Policy for Sustainable Development, 56(1), 18-24.

Munang, R., Thiaw, I., Alverson, K., Mumba, M., Liu, J., \& Rivington, M. (2013). Climate change and Ecosystem-based Adaptation: A new pragmatic approach to buffering climate change impacts. Current Opinion in Environmental Sustainability.

https://doi.org/10.1016/j.cosust.2012.12.001

Mwangi, W. M. (1996). Low use of fertilizers and low productivity in sub-Saharan Africa. Nutrient Cycling in Agroecosystems, 47(2), 135-147. https://doi.org/10.1007/BF01991545

Nabalegwa, M., Buyinza, M., \& Lusiba, B. (2007). Changes in soil chemical and physical properties due to land use conversion in Nakasongola district, Uganda. Indonesian Journal of 
Geography, 38(2), 1.

Naidoo, R., \& Adamowicz, W. L. (2005). Biodiversity and nature-based tourism at forest reserves in Uganda. Environment and Development Economics, 258129109(10), 159-178. https://doi.org/10.1017/S1355770X0400186X

Namaalwa, S., Van dam, A. A., Funk, A., Ajie, G. S., \& Kaggwa, R. C. (2013). A characterization of the drivers, pressures, ecosystem functions and services of Namatala wetland, Uganda. Environmental Science and Policy, 34, 44-57.

https://doi.org/10.1016/j.envsci.2013.01.002

Nimusiima, A., Basalirwa, C. P. K., Majaliwa, J. G. M., Otim-Nape, W., Okello-Onen, J., Rubaire-Akiiki, C., Konde-Lule, J., \& OgwalByenek, S. (2013). Nature and dynamics of climate variability in the Uganda cattle corridor. African Journal of Environmental Science and Technology, 7(8), 770-82.

Osano, P. M., Said, M. Y., de Leeuw, J., Moiko, S. S., Kaelo, D. O., Schomers, S., Ogutu, J. O. (2013). Pastoralism and ecosystem-based adaptation in Kenyan Masailand. International Journal of Climate Change Strategies and Management, 5(2), 198-214.

https://doi.org/10.1108/17568691311327596

Osbahr, H., Dorward, P., Stern, R., \& Cooper, S. (2011). Supporting agricultural innovation in Uganda to respond to climate risk: linking climate change and variability with farmer perceptions. Experimental Agriculture, 47(02), 293-316

Pasquini, L., \& Cowling, R. M. (2014). Opportunities and challenges for mainstreaming ecosystem-based adaptation in local government: evidence from the Western Cape, South Africa. Environment, Development and Sustainability, 17(5), 1121-1140.

https://doi.org/10.1007/s10668-014-9594-X

Perry, G. L. W., \& Millington, J. D. A. (2008). Spatial modelling of succession-disturbance dynamics in forest ecosystems: Concepts and examples. Perspectives in Plant Ecology, Evolution and Systematics, 9(3-4), 191-210. https://doi.org/10.1016/j.ppees.2007.07.001

Pramova, E., Locatelli, B., Brockhaus, M., \& Fohlmeister, S. (2012). Ecosystem services in the National Adaptation Programmes of Action. Climate Policy, 12(4), 393-409. https://doi.org/10.1080/14693062.2011.647848

Price, K., Roburn, A., \& MacKinnon, A. (2009). Ecosystem-based management in the Great Bear Rainforest. Forest Ecology and Management, 258(4), 495-503.

https://doi.org/10.1016/j.foreco.2008.10.010

Raudsepp-Hearne, C., Peterson, G. D., \& Bennett, E. M. (2010). Ecosystem service bundles for analyzing tradeoffs in diverse landscapes. Proceedings of the National Academy of Sciences of the United States of America, 107(11), 5242-7.

https://doi.org/10.1073/pnas.0907284107

Rickards, L., \& Howden, S. M. (2012). Transformational adaptation: Agriculture and climate change. In Crop and Pasture Science, 63, 240-250. https://doi.org/10.1071/CP11172 
Rojas, O., Vrieling, A., \& Rembold, F. (2011). Assessing drought probability for agricultural areas in Africa with coarse resolution remote sensing imagery. Remote Sensing of Environment, 115(2), 343-352. https://doi.org/10.1016/j.rse.2010.09.006

Seidl, R., Spies, T. A., Peterson, D. L., Stephens, S. L., \& Hicke, J. A. (2016). Searching for resilience: Addressing the impacts of changing disturbance regimes on forest ecosystem services. Journal of Applied Ecology, 53(1), 120-129.

https://doi.org/10.1111/1365-2664.12511

Silvestrini, R. A., Soares-Filho, B. S., Nepstad, D., Coe, M., Rodrigues, H., \& Assun????o, R. (2011). Simulating fire regimes in the Amazon in response to climate change and deforestation. Ecological Applications, 21(5), 1573-1590. https://doi.org/10.1890/10-0827.1

Slegers, M. F. W., \& Stroosnijder, L. (2008). Beyond the desertification narrative: a framework for agricultural drought in semi-arid East Africa. Ambio, 37(5), 372-80. https://doi.org/10.1579/07-a-385.1

Staudhammer, C. L., Escobedo, F. J., Holt, N., Young, L. J., Brandeis, T. J., \& Zipperer, W. (2015). Predictors, spatial distribution, and occurrence of woody invasive plants in subtropical urban ecosystems. Journal of Environmental Management, 155, 97-105.

https://doi.org/10.1016/j.jenvman.2015.03.012

Stringer, L. C., Dyer, J. C., Reed, M. S., Dougill, A. J., Twyman, C., \& Mkwambisi, D. (2009). Adaptations to climate change, drought and desertification: local insights to enhance policy in southern Africa. Environmental Science and Policy, 12(7), 748-765.

https://doi.org/10.1016/j.envsci.2009.04.002

Tin, H. Q., Berg, T., \& Bjørnstad, Å. (2001). Diversity and adaptation in rice varieties under static (ex situ) and dynamic (in situ) management. In Euphytica, 122, 491-502. https://doi.org/10.1023/A:1017544406975

Turner, W., Spector, S., Gardiner, N., Fladeland, M., Sterling, E., \& Steininger, M. (2003). Remote sensing for biodiversity science and conservation. Trends in Ecology and Evolution. https://doi.org/10.1016/S0169-5347(03)00070-3

UBOS. Statistical Abstracts from National Livestock senses. Republic of Uganda. 2008.

Usali, N., \& Ismail, M. H. (2010). Use of remote sensing and GIS in monitoring water quality. Journal of Sustainable Development, 3(3), 228-238. https://doi.org/10.5539/jsd.v3n3p228

Vaneeckhaute, C., Meers, E., Michels, E., Buysse, J., \& Tack, F. M. G. (2013). Ecological and economic benefits of the application of bio-based mineral fertilizers in modern agriculture. Biomass and Bioenergy, 49, 239-248. https://doi.org/10.1016/j.biombioe.2012.12.036

Wamsler, C., Luederitz, C., \& Brink, E. (2014). Local levers for change: Mainstreaming ecosystem-based adaptation into municipal planning to foster sustainability transitions. Global Environmental Change, 29, 189-201. https://doi.org/10.1016/j.gloenvcha.2014.09.008

Wertz-Kanounnikoff, S., Locatelli, B., Wunder, S., \& Brockhaus, M. (2011). 


\section{Macrothink}

Environmental Management and Sustainable Development

ISSN 2164-7682

2017, Vol. 6, No. 2

Ecosystem-based adaptation to climate change: What scope for payments for environmental services? Climate and Development, 3(2), 143-158.

https://doi.org/10.1080/17565529.2011.582277

Zarafshani, K., Sharafi, L., Azadi, H., Hosseininia, G., De Maeyer, P., \& Witlox, F. (2012). Drought vulnerability assessment: The case of wheat farmers in Western Iran. Global and Planetary Change, 98-99, 122-130. https://doi.org/10.1016/j.gloplacha.2012.08.012

Zziwa, E., Kironchi, G., Gachene, C., Mugerwa, S., \& Mpairwe, D. (2012). The dynamics of land use and land cover change in Nakasongola district. Journal of Biodiversity and Environmental Sciences, 2(5), 61-73.

\section{Copyright Disclaimer}

Copyright for this article is retained by the author(s), with first publication rights granted to the journal.

This is an open-access article distributed under the terms and conditions of the Creative Commons Attribution license (http://creativecommons.org/licenses/by/3.0/). 